Egyptian Journal of Aquatic Biology \& Fisheries

Zoology Department, Faculty of Science,

Ain Shams University, Cairo, Egypt.

ISSN $1110-6131$

Vol. 25(6): 503 - 512 (2021)

www.ejabf.journals.ekb.eg

\title{
Effect of diel variation on trawl fishery-catch rates in the Gulf of Suez, Red Sea, Egypt
}

\author{
El-Azab E. Badr El-Bokhty ${ }^{1}$ *; Azza A. El-Ganainy ${ }^{1}$; MagdyT. Khalil ${ }^{2}$; \\ Fawzia A. Abd El-Rahman ${ }^{2}$ and Mahmoud A. Saber ${ }^{1}$ \\ 1. National Institute of Oceanography and Fisheries, NIOF, Egypt \\ 2. Zoology Dept., Fac. Sci. Ain Shams Univ., Egypt \\ *Corresponding Author: elbokhty@yahoo.com
}

\begin{abstract}
ARTICLE INFO
Article History:

Received: Nov. 2, 2021

Accepted: Dec. 17, 2021

Online: Dec. 29, 2021

Keywords:

Catch rate,

Diurnal variation,

Trawl fishery,

Gulf of Suez

\section{ABSTRACT}

Two experimental trawl surveys were conducted in the Gulf of Suez during[m1] April (spring) and November (autumn) 2014. The current study addressed the effect of the diurnal variables (day and night) on the catch rates of three fish species (lizard fish Saurida undosquamis, horse mackerel Trachurus indicus, threadfin bream Nemipterus japonicus), two cephalopods (cuttlefish Sepia sp, Indian squid Loligo duvauceli) and two crustaceans (Crab Portunus pelagicus and shrimp Penaeus sp.). In both surveys, the highest catch was caught just after dusk during the daytime, while during the night, it was recorded in the middle of the night. In spring, day and night mean catch rates were not significantly different $(\mathrm{P}>0.01)$ for all species. While in autumn, the rates of Trachurus indicus, Loligo duvauceli, and Penaeus sp. were significantly different $(\mathrm{P}<0.01$ and $\mathrm{T}$ values were 2.80, 3.28 and 2.34, respectively). In addition, those of Saurida undosquamis, Nemipterus japonicus, Sepia sp., and Portunus pelagicus were not significantly different $(\mathrm{P}>0.01)$. The results of the study revealed that both the early morning and the late evening are the best times for fishing.
\end{abstract}

\section{INTRODUCTION}

The Gulf of Suez is a very important fishing ground which helps in lessepsian migration of some species from the Red Sea to the Mediterranean Sea via the Suez Canal ( El Ganainy et al., (2018). The Egyptian bottom trawl fishing is carried out 24/7 . Diel vertical migration (DVM), displayed by a variety of fish as well as other marine and freshwater taxa, is an important representative of such light impacting behavior (Ringelberg, 1991; Watanabe et al., 1999; Pearre, 2003).

The bottom trawl is the only method used in the Red Sea to estimate the abundance of demersal fish species (Saber, 2014). The most commercially important species in the bottom trawl fisheries of the NW Red Sea, in the Gulf of Suez and its adjacent area include the following species: the lizardfish Saurida undosquamis, the threadfin bream Nemipterus japonicus, the striped piggy Pomadasys stridens, in addition to the penaeid 
shrimps, such as Penaeus semisulcatus, Penaeus japonicus and Penaeus latisulcatus (Yousif, 2003 ; El-Etreby et al., 2013; El Ganainy et al., 2018).

Many factors affect the catch rate of trawl fishes, among which the efficiency, setup and operating of the net, environmental conditions, and the behavior of the fish are considered (Francis \& Williams, 1995).

In the literature review, three types of vertical migrations have been discussed; namely, the first migration which represents the strong migrants that occurs extensively in a vertical movement transferring the fish species between the mesopelagic and the epipelagic; the second migration that forms the weak- migrants and undertakes little diel vertical migration; and the third is the non-migrants, which undergoes no vertical migration (Collins et al., 2008; Oliver et al., 2012; Sutton, 2013).

Diel vertical migration is an important example to observe the behavior of marine resources in relation to environmental factors, especially light and temperature; sometimes the presence of food is also regarded as a factor (Ringelberg, 1991; Watanabe et al., 1999; Pearre, 2003). Previous studies that assessed the diel vertical migration of some species behavior have focused on comparing the diurnal variations (day and night) and addressing the effect of this migration on the distribution of a population (Cardinale et al., 2003; Orlowski, 2005; Gjelland et al., 2009).

The present study is a part of a wide- ranged work studying the spatial and temporal variabilities in relation to the abundance of demersal fish catch at the Gulf of Suez. It was conducted to evaluate the effect of diurnal variations on the bottom trawl catch.

\section{MATERIALS AND METHODS}

The data were collected from two bottom trawl surveys conducted during April and November 2014. The surveys were carried out on a commercial trawler. More than 226 hauls were recorded on board of fishing vessel. The bottom trawl was towed at speeds of about 2.8 to 3.3 knots and at water depths ranging from 5 to $65 \mathrm{~m}$.

In the first survey, nineteen successful tows were taken during day light. The day tows were conducted between an hour after sunrise to an hour before sunset. The towing time varied between 139 and $220 \mathrm{~min}$ at about 3 knots speed. During the night, eighteen successful tows were taken. The night tows were conducted between an hour after sunset to an hour before sunrise. The towing time ranged from 90 to $200 \mathrm{~min}$ at about 3 knots speed.

In the second survey, thirty-five successful tows were conducted during the day's light. The number of day and night hauls were 35 (46\%) and 40 hauls (54\%), respectively. 


\section{Relative abundance}

Indices of abundance were calculated from April and November 2014 with respect to bottom trawl survey. Haul data for commercial species were selected based on their importance in trawl fishery of the Gulf of Suez. For each individual, the CPUE survey was defined as the amount of individuals caught per hour and was assumed as an appropriate index for abundance. To record the CPUE, the following equation was considered:

$$
\text { CPUE }=\text { Total catch } / \text { No. of fishing hours }
$$

\section{Statistical analysis}

The results were statistically recorded using Kolmogorov-Smirnov. The Levene tests were used (Zar, 1999) to analyze the normality of the data and the homogeneity of variances. T-test was applied to independent variables to investigate whether the mean CPUE differed with respect to day and night for the same species and durations by using Info Stat (data analysis software system) version (2012).

\section{RESULTS}

During the autumn survey, the mean catch rate was $40.3 \mathrm{Kg} / \mathrm{hr}$ at daytime operation and $26.4 \mathrm{~kg} / \mathrm{hr}$ during the nighttime operation. The mean catch rates were higher during daytime than at night, recording a significant difference $(P<0.05)$. While in the spring survey, the mean catch rate was $13.49 \mathrm{Kg} / \mathrm{hr}$ at daytime and $16.18 \mathrm{Kg} / \mathrm{hr}$ during nighttime. The mean catch rate was lower during day time compared to the night, with no significant difference $(P>0.05)$ was detected (Table 1).

Table 1. Compared diel variability of total trawl catch during autumn and spring (2014)

\begin{tabular}{|c|c|c|c|c|c|c|}
\hline \multirow{2}{*}{ Season } & \multicolumn{2}{|c|}{ Day } & \multicolumn{2}{c|}{ Night } & \multirow{2}{*}{ T } & \multirow{2}{*}{$\mathrm{P}$} \\
\cline { 2 - 5 } & Catch $(\mathrm{Kg})$ & Catch $/ \mathrm{hr}$ & Catch $(\mathrm{Kg})$ & catch $/ \mathrm{hr}$ & & \\
\hline Autumn & 3410.5 & 40.3 & 2599.5 & 26.41 & 2.22 & 0.03 \\
\hline Spring & 709.5 & 13.49 & 738 & 16.18 & 0.49 & 0.65 \\
\hline
\end{tabular}

In the current study, the trawl fishing experiment was carried out at all the day-times (i.e. during 24-hour period). The relative catch per hour showed that the early morning of daytime was the best time for gathering a high amount of catch. On the other hand at nighttime, the good time for catching a bulk of fish was at the middle of the night (Fig. $1)$. 

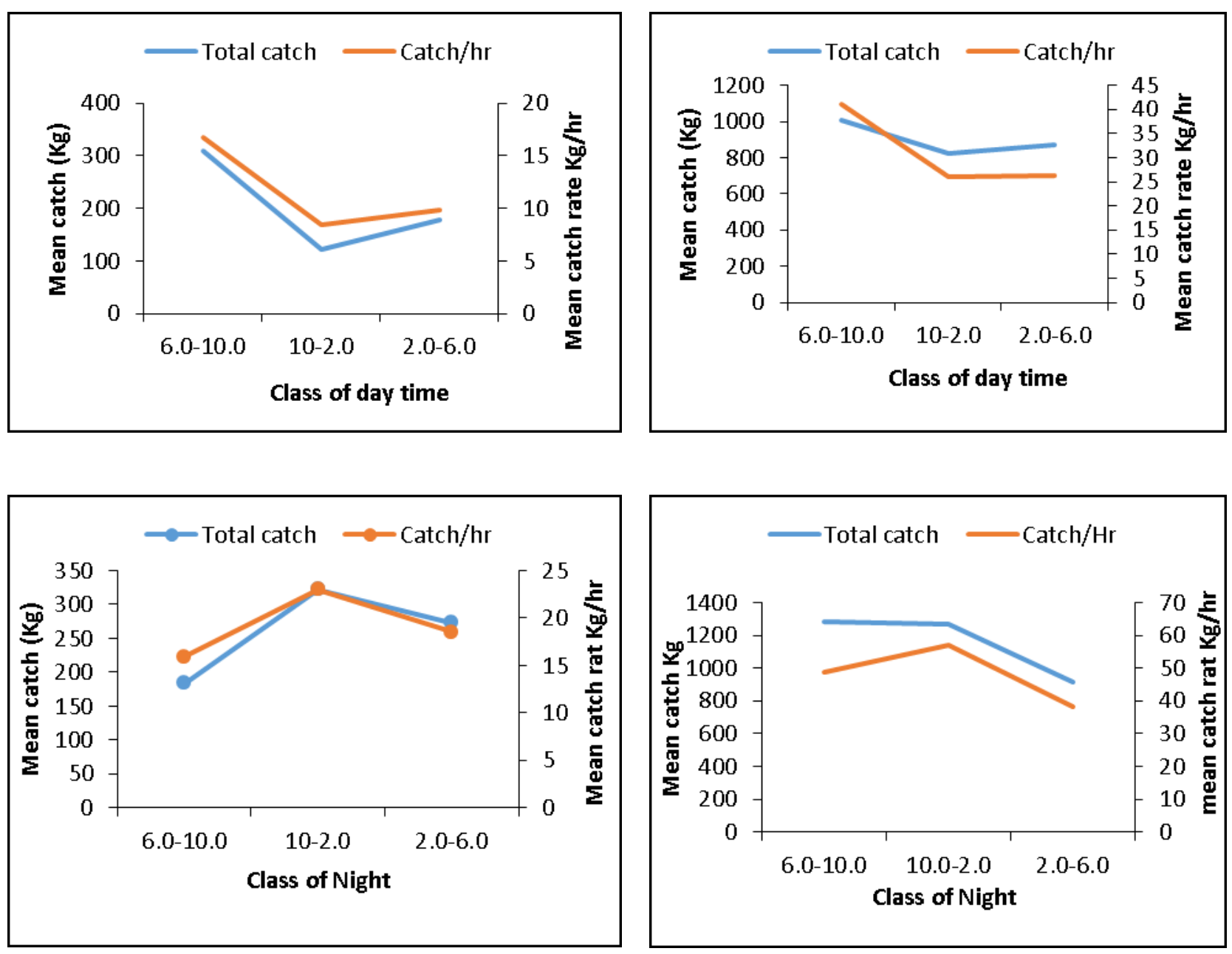

Fig. 1. Mean total catch and mean catch rate of different classes of day and night times during spring and autumn fishing seasons

The catch per hour of night hauls for lizard fish, horse mackerel, threadfin bream, Indian squid and cuttlefish were higher than those recorded at daytime. On the other hand, shrimp catch was present only in daytime. Statistically, day and night mean catch rates were not significantly different $(\mathrm{p}>0.05)$ with $\mathrm{T}$-value $(0.36,0.40,-024,0.71)$ for lizard fish, threadfin bream, horse mackerel, and Indian squid, respectively.

During autumn survey, the catch per hour of fish species, such as Saurida undosquamis, Trachurus indicus, Nemipterus japonicus, Sepia savignyi and Loligo duvauceli was higher at daytime than at night. While in Penaeus species, the catch per hour was higher at nighttime than at day light. On the other hand, Portunus pelagicus was recorded only at night. During the autumn cruise, day and night mean catch rates of Horse mackerel and Indian squid showed highly significant difference $(\mathrm{P}<0.01$ and $\mathrm{T}$ values were 2.8 and -3.28 , respectively). Additionally, the mean catch rate of shrimp was significantly different $(\mathrm{P}=0.021)$, and the $\mathrm{T}$. value was -2.34 . While, the mean catch rates 
of lizard fish, thread fin bream, cuttlefish were not significantly different $(\mathrm{P}>0.01)$, and the T. values were $1.71,0.63$ and 0.57 , respectively (Table 2).

Table 2. Diel catch estimates of three finfish, two cephalopods and two Crustaceans caught by bottom trawl net in the Gulf of Suez (2014)

\begin{tabular}{|c|c|c|c|c|c|c|c|}
\hline \multirow{3}{*}{ Species } & \multicolumn{7}{|c|}{ Spring survey } \\
\hline & \multicolumn{2}{|c|}{ Daytime } & \multicolumn{2}{|c|}{ Night } & \multicolumn{3}{|c|}{ Statistical analysis } \\
\hline & $\begin{array}{c}\text { Catch } \\
(\mathrm{kg})\end{array}$ & $\begin{array}{c}\text { Catch/ } \\
\text { hr. }\end{array}$ & Catch $(\mathrm{kg})$ & $\begin{array}{c}\text { Catch } \\
\text { /hr. }\end{array}$ & $\mathrm{T}$ & D.f.* & $\mathrm{P}$ \\
\hline Saurida undosquamis & 389 & 7.397 & 346.5 & 7.597 & 0.36 & 36 & 0.72 \\
\hline Nemipterus japonicus & 51.5 & 0.979 & 43 & 0.943 & 0.4 & 36 & 0.69 \\
\hline Trachurus indicus & 122 & 2.32 & 146.5 & 3.212 & -0.24 & 36 & 0.81 \\
\hline Penaeus sp. & 10 & 0.19 & 0 & 0 & - & 3 & - \\
\hline Sepia sp. & 2 & 0.038 & 5 & 0.11 & -0.56 & 4 & 0.58 \\
\hline Loligo duvauceli & 27.5 & 0.523 & 39 & 0.855 & 0.71 & 24 & 0.48 \\
\hline \multirow[t]{2}{*}{ Portunus pelagicus } & 0 & 0 & 0 & 0 & & & \\
\hline & \multicolumn{7}{|c|}{ Autumn survey } \\
\hline Saurida undosquamis & 1030 & 12.09 & 896 & 9.1 & 1.71 & 72 & 0.09 \\
\hline Nemipterus japonicus & 595 & 6.56 & 561 & 5.7 & 0.63 & 66 & 0.49 \\
\hline Trachurus indicus & 631.5 & 7.41 & 303 & 3.08 & 2.8 & 72 & 0.006 \\
\hline Penaeus sp. & 81 & 0.95 & 184 & 1.87 & 2.34 & 20 & 0.02 \\
\hline Sepia sp. & 121 & 1.42 & 117 & 1.19 & -0.57 & 40 & 0.56 \\
\hline Loligo duvauceli & 256 & 3.01 & 68.5 & 0.7 & -3.28 & 40 & 0.0021 \\
\hline Portunus pelagicus & 0 & 0 & 10 & 0.1 & - & 2 & - \\
\hline
\end{tabular}

* D.f.: Degree of freedom

\section{DISCUSSION}

The principal demersal fish populations of trawl fishing grounds perform diel vertical migrations together with the zooplankton they feed on. These species stay down the water column during daytime and move to the surface waters at night or the reverse. The behavior of many fish species is affected by the diel cycle (Helfman, 1993). The present results revealed that sometimes the catch date varied between day and night in the same season, and sometimes the catch rate did not vary. In the present work, specifically in fall, significant differences were recorded between day and night mean catch rates. While in the spring, no significant difference was detected. This result coincides with that of Hart et al. (2010) who noted large differences in the relative abundance between day and night. Moreover, Gordon (1977) reported that the catch per hour by mid water trawl is higher during darkness and added that the catch rates of the juvenile whiting are slightly higher during the day, whereas no differences were observed regarding the adult whiting. Sagarese et al. (2016) realized that, the daytime survey catchability was 
significantly higher than nighttime catchability for most species during autumn in the Northeast of the U.S. Continental Shelf Large Marine Ecosystem. Differences in trawl catch rates between day and night may be attributed to fish behavior, notably vertical migration or gear avoidance reactions.

Adlerstein and Ehrich (2002) recorded significant fluctuation; not only between day and night hauls but also within daytime hours in catch rates of juvenile and adult haddock, juvenile whiting, Norway pout, herring and dab from summer bottom trawl surveys in the North Sea.

The mean catch rates of lizard fish, threadfin bream, horse mackerel, and Indian squid were not significantly different, and shrimp was present only in day time during spring. The present result is close to that of Yousif (2004) who found that, the higher mean catch rate per hour of $N$. japonicus in the Gulf of Suez was $6.4 \mathrm{Kg} / \mathrm{hr}$ for day and $3.7 \mathrm{~kg} / \mathrm{hr}$ for night. Consequently, the day and night mean of catch per hour rates were significantly different $(\mathrm{P}<0.0210)$. The fall season's results indicate that the catch rates of fish species were slightly different in daytime than at night. Day-night differences in catchability have also been reported in other fish species and other fishing grounds in response, depending on the species and sites (Cardinale et al., 2003; Orlowski, 2005; Gjelland et al., 2009).

Diurnal burying activity is common in the majority of penaeids (Bishop et al. 2008). The burrowing behavior of penaeids is a strategy for energy conservation and a means of defense against potential predators (Kutty \& Murugopoopathy 1968; Dall et al., 1990). Shrimps that bury themselves in the substrate during the day are protected against predators feeding in this period and are less active than those that do not bury themselves. Their results are directly comparable with the current findings, where the catch rate of shrimp and crab were higher in nighttime than at day in autumn survey. However, for shrimp, the present results disagree with those of Yousif (2003) who reported that, daynight times have no significant influence on the length catchability variation of the shrimp in the Gulf of Suez. Whereas, the current result concurs with that of Simoes et al. (2010) who found that, for shrimps in Southeastern Brazil, large numbers of were caught at daytime. Similarly, Ibrahim et al. (2011) concluded that the shrimp catch rate is relatively higher during sunrise and daytime compared to sunset and nighttime in both east and west sides of the Mediterranean Sea.

\section{CONCLUSION}

Diel variation in commercial CPUE of trawl fishery was significantly higher in autumn during daytime than at night. While in spring, the difference between day and night was non- significant. This variation may be attributed to the amount of biomass and time of fishing. Furthermore, day-night difference in CPUE increased with the incease in the density of penaeid, which may be linked to the vertical migration and the nocturnal feeding behavior of the penaeid, spending most of the day buried in sediment and emerge to forage at night. During both surveys, the highest catch rate was recorded after dusk and 
in the middle of the night. This study point may be attributed to the relation between fish behavior and physical parameters, including both temperature and tide movement.

\section{Acknowledgement}

The research is a part of the Ph.D. thesis entitled "Size selection by diamond and square mesh codends for the most commercial demersal fishes in the Gulf of Suez ", which in turn, is a part of the research project number 5628 entitled "Stock Assessment and Gear Description of the Red Sea and Gulf of Suez Fisheries for Proper Management". Thus, this work was sponsored by the Science and Technology Development Fund (STDF).

\section{REFERENCES}

Adlerstein, S.A. and Ehrich, S. (2002). Effect of deviation from target speed and time of day on catch rates of some abundant species under North Sea international bottom trawl survey protocol conditions. ICES Journal of Marine Science, 59:594603.

Aglen, A.; Engas, A. ; Huse, I. ; Michalsen, K. and Stensholt, B.K., (1999). How vertical fish distribution may affect survey results. ICES J. Marine Sci. 56, 345360.

Al-Kholy, A. A and El-Hawary, M. M. (1970). Some Penaeids of the Red Sea Bull, Inst. Ocean. Fish. A. R.E., 1:339-378.

Atkinson, D. B. (1989). Diel movements of beaked redfish and the implications of these for stratified random bottom trawl estimates of biomass and abundance. N. Am. J. Fish. Manage. 9: 163-170.

Bishop, J. M. Ye; Alsaffar, Y.; AL-Foudari, A. H.M. and AL-Jazzaf, S. (2008). Diurnal and nocturnal catchability of Kuwait's commercial shrimps. Fish Res 94: $58-72$.

Cardinale, M. ; Casini, M. ; Arrhenius, F. and Håkansson, N. (2003). Diel spatial distribution and feeding activity of herring (Clupea harengus) and sprat (Sprattus sprattus) in the Baltic Sea. Aquat. Living Resour. 16, 283-292.

Collins, M.A. ; Xavier, J.C. ; Johnston, N.M. ; North, A.W. ; Enderlein, P. ; Tarling, G.A. ; Waluda, C.M. ; Hawker, E.J. and Cunningham, N.J. (2008). Patterns in the distribution of myctophid fish in the northern Scotia Sea ecosystem. Polar Biol. $31,837-851$.

Dall, W. ; Hill B. J. ; Rothilsberg, P.C. and Staples, D. J. (1990). The biology of the Penaeidae. Advances in Marine Biology. BLAXTER JHS AND SOUTHWARD AJ (Eds), San Diego, Academic Press, p. 1-489.

El-Etreby S. G.; El Ganainy A. A.; Saber M. A.; El Elwany M. A and A. E. El Bokhty, (2013). Age, growth and reproduction of the lizard fish Saurida 
undosquamis from the Gulf of Suez, Red Sea, Egypt. Egypt. J. Aquat. Biol. \& Fish., Vol. 17 No. 3, 25-34.

El Ganainy, A. A. ; Khalil, M. T. ; El Azab, E. B. ; Saber, M. A. and Abd ElRahman F. A. (2018). Assessment of three nemipterid stocks based on trawl surveys in the Gulf of Suez, Red Sea. Egyp. J. of Aqua. Res.44(1):45-49.

Ellis, N. and Wang. Y. (2006). Effects of fish density distribution and effort distribution on catchability. ICES Jo. of Mar. Sci. 64(1):178-191.

Francis, M. P. and Williams, M. W. (1995). Diel variation in trawl catch rates of Pagrusauratus (Sparidae), Fisheries Research 24, 301-310.

Francis, R. I. C. C. ; Hurst, R. J. and Renwick, J. A. (2003). Quantifying annual variation in catchability for commercial and research fishing. U.S. National Marine Fisheries Service. Fish. Bull. 101:293-304.

Fraser, H. M. ; Greenstreet, S. P. R. and Piet, G. J. (2007). Taking account of catchability in ground fish survey trawls: implications for estimating demersal fish biomass. ICES J. of Mar. Sci. 64(9):1800-1819.

Gauthier, S. \& Rose, G. A. (2005). Diel vertical migration and shoaling heterogeneity in Atlantic redfish: effects on acoustic and bottom-trawl surveys. ICES Jo. of Mar. Sci. 62(1):75-85.

Gjelland, K.Ø.; Bøhn, T. ; Horne, J.K. ; Jensvoll, I. ; Knudsen, F.R. and Amundsen, P.A. (2009). Planktivore vertical migration and shoaling under a subarctic light regime. Can. J. Fish. Aquat. Sci. 66, 525-539.

Godø, O. R. (1994). Factors affecting the reliability of ground fish abundance estimates from bottom trawl surveys. Pages 166-195 in A. Fernö and S. Olsen, editors. Marine fish behaviour in capture and abundance estimation. Fishing News Books, Blackwell Scientific Books, London.

Godø, O. R. ; Walsh, S. J. and Engås, A. (1999). Investigating density-dependent catchability in bottom-trawl surveys. ICES. J. of Mar. Sci., 56(3):292-298.

Gordon, J. D. M. (1977). The fish populations in inshore waters off the West Coast of Scotland: The distribution, abundance and growth of the whiting (Merlangius merlangius L.). J. of Fish. Bio., 10(6): 587-596.

Hart, T. D. ; Julia, E. R. ; Wakefield, W.W. and Heppell, S.S. (2010). Day and night abundance, distribution, and activity patterns of demersal fishes on Heceta Bank, Oregon. Fishery Bulletin 108(4).

Helfman, G. S. (1993). Fish behavior by day, night and twilight. In Behaviour of teleost fishes, 2ndedn, pp. 479-512. Ed. By T. J. Pitcher. Chapman and Hall, London.

Hjellvik, V., ; Godø, O.R., and Tjøstheim, D. (2004). Decomposing and explaining the variability of bottom trawl survey data from the Barents Sea. Sarsia 89, 196-210.

Ibrahim, M. A. ; Hasan, M.W.A. ; El-Far, A. M. M. ; Farrag, E. F. E. and Farrag, M. M. S. (2011). Deep Sea Shrimp Resources in the South Eastern Mediterranean Waters of Egypt. Egypt. J. Aq. Res., 37(2):131-137. 
Korsbrekke, K. and Nakken, O. (1999). Length and species-dependent diurnal variation of catch rates in the Norwegian Barents Sea bottom-trawl surveys. ICES J. Marine Sci. 56, 284-291.

Kutty, M. N. and Murugopoopathy, G. (1968). Diurnal activity on the prawn PenaeussemisulcatusDeHaan. J Mar BiolAssoc India 10: 95-98.

Michalsen, K. ; Godø, O. R. and Fernō, A. (1996). Diel variation in the catchability of gadoids and its influence on the reliability of abundance indices. ICES J. of Mar. Sci. 53(2):389-395.

Olivar, M.P.; Bernal, A.; Molí, B.; Peña, M.; Balbín, R.; Castellón, A; Miquel, J. and Massutí, E. (2012). Vertical distribution, diversity and assemblages of mesopelagic fishes in the western Mediterranean. Deep Sea Res. Part I Oceanogr. Res. Pap. 62, 53-69.

Orlowski, A. (2005). Experimental verification of the acoustic characteristics of the clupeoid diel cycle in the Baltic. ICES J. Mar. Sci. 62, 1180-1190.

Pearre, S. (2003). Eat and run? The hunger/satiation hypothesis in vertical migration: history, evidence and consequences. Biol. Rev. Camb. Philos. Soc. 78, 1-79.

Ringelberg, J. (1991). A mechanism of predator mediated induction of diel vertical migration in Daphnia hyalina. J. Plankt. Res. 13, 83-89.

Saber, M. A. (2014). Efficiency and selectivity of trawl net, its design characters and effect on demersal fish population at the Gulf of Suez. M.sc. Thesis. Fac. Sci. Suez Canal Univ.

Sagarese, S. R. ; Frisk, M. G. ; Cerrato, R. M.; Sosebee, K. A.; Musick, J. A. and Rago, P. J. (2016). Diel Variations in survey catch rates and survey catchability of spiny dogfish and their pelagic prey in the Northeast U.S. continental shelf large marine ecosystem. Marine and Coastal Fisheries. Dynamics, Management, and Ecosystem Science. 8 (1): 244-262.

Salthaug, A. and Aanes, S. (2003). Catchability and the spatial distribution of fishing vessels. Canadian J. of Fish. and Aqua. Sci. 60:259-268.

Simoes, S. M. ; Costa, R. C. ; Fransozo A. \& Castilho, A. (2010). Diel variation in abundance and size of the sea bob shrimp Xiphopenaeuskroyeri (Crustacea, Penaeoidea) in the Ubatuba region, Southeastern Brazil.Annals of the Brazilian Academy of Sciences. 82(2): 369-378.

Sutton, T.T., (2013). Vertical ecology of the pelagic ocean: classical patterns and new perspectives. J. Fish. Biol. 83, 1508-1527. http://dx.doi.org/10.1111/jfb.12263. Tont, S., 1976. Deep scattering layers: patterns in the Pacific. In CalCOFI Rep. Vol. 18. pp. 112-117.

Trenkel, V. M. ; Francis, R. I. C. C. ; Lorance, P. ; Mahévas, S. ; Rochet, M. and Tracey, D. M. (2004). Availability of deep-water fish to trawling and visual observation from a remotely operated vehicle (ROV). Mar. Eco. Progress Series 284:293-303 
Yousif, A. (2003). Fisheries of three shrimps Penaeus japonicus Penaeuslatisulcatus in the Gulf of Suez .Bull. Nat. Inst. Of oceanogr\& fish. A. R. E. (29): 87-116.

Yousif, A. (2004). Variation of catchability and length of the threadfin bream (Nemipterus japonicus) from the NW Red Sea trawl fishery. Proc.I. C. B. S. 3(1); 414-434.

Watanabe, H.; Moku, M.; Kawaguchi, K.; Ishimaru, K. and Ohno, A. (1999). Diel vertical migration of myctophid fishes (Family myctophidae) in the transitional waters of the western North Pacific. Fish. Oceanogr. 8, 115-127.

Zar, J.H. (1999). Bio statistical Analysis, 4th Edition. Prentice-Hall, Upper Saddle River, NJ 978p. 